for updated data and information relates to environment and to review the available information of land resource. The methodology used to collect data and information consisted of reference to the literature through recent publications, annual reports, periodicals and internet, visits to relevant institutions and personal communication with experts and officials. The results revealed that some of the authorities are able to maintaining their information regularly where as few are unable to maintain due to lack of their resources and man power. Few of them can be summarized as follows. Latest Soil Classification according to international methods and development of a soil data base and soil map for wet and intermediate zones has published in 2005 by the Soil Science Society of Sri Lanka. The existing map of 24 agro ecological sub regions (1975) were updated into 46 sub regions in 2003. Preparations of hazardous maps for major areas in ten districts which are prone to landslide have been carried out by NBRO and few districts were already completed. At present the Department of Survey isplanning to publish the latest version of the National Atlas with up dated data and information and it includes distribution of almost all the natural resources and present land uses, further as a new chapter the tsunami information is also included. The Clean Air initiative, which releases regular ambient air quality monitoring reports, sets an important example in dissemination of public environmental information. Furthermore, the extent of coral reef in coastal area except North and East has been carried out by the NARA after the tsunami disaster. Survey of mineral resources of the country is been carried out by the Dept.of. Geological Survey and Mine Bureau as an ongoing project. Study emphasized the need for integration of the fragmented and sectoral information of the individual institutes and the need for timely reliable and systematic data base on environmental information that could aid in better decision making and management processes.

\title{
034 \\ Assessment of soil erosion hazard of Victoria catchment area using GIS as a tool
}

\author{
K P G W Senadeera ${ }^{1}$, S Piyasiri ${ }^{1}$ and K D W Nandalal ${ }^{2}$ \\ 'Department of Zoology, University of Sri Jayewardenepura, Nugegoda, Sri Lanka. \\ ${ }^{2}$ Department of Civil Engineering, University of Peradeniya, Sri Lanka.
}

Victoria reservoir is located at an elevation of $340 \mathrm{~m}$ to $440 \mathrm{~m}$ with a geographical position of $7^{\circ} 15^{\prime}$ to $7^{\circ} 19^{\prime} \mathrm{N}$ and $80^{\circ} 39^{\prime}$ to $80^{\circ} 48^{\prime} \mathrm{E}$ which has been constructed by damming the River Mahaweli at Victoria fall, in Sri Lanka in 1983. The reservoir storage capacity is 721.2 MCM and upstream dam site comprises $1338 \mathrm{~km}^{2}$ in the districts of Kandy, Nuwara-Eliya and Matale. The elevation of the catchment ranges from $340 \mathrm{~m}$ to $2100 \mathrm{~m}$.

Soil erosion is a major water quality issie in the upland reservoirs. The objective of this paper is to analyze catchment issues contributing to soil erosion in the Victoria reservoir and to evaluate the soil erosion risk areas in the catchment. Study was carried out from 2002 to 2004.

Soil erosion occurs due to natural causes such as rain fall, rainfall runoff and wind, and due to human activities. Universal Soil Loss Equation ( $A=R K L S C P$ ) introduced by Wischmeier and Smith in 1965 is a most widely used method for estimating soil erosion. This encounters detachment of soil particles and its transport by raindrops and surface runoff, which depends on the rainfall erosivity (R), erodibility of soil (K), slope length factor (LS), cover and management factor (C) and the support practice factor of the equation.

The data on erosivity points were interpolated with $50 \mathrm{~m}$ resolution grid cells. The erodibility value relevant to each soil group was entered into the attribute table, which was converted into grid cells with $50 \mathrm{~m}$ resolution, containing soil erodibility values. The Triangulated Irregular Network (TIN) was created by contour interpolating with $20 \mathrm{~m}$ interval, and grid cell was $50 \mathrm{~m}$. Using TIN, slope percentages map was derived, which was used to obtain LS factor. The $\mathrm{C}$ factor values relevant to each landuse type were entered into the attribute table. The map was converted into grid cells with 50 $\mathrm{m}$ resolution, containing $\mathrm{C}$ factor values.

The soil erosion of the Victoria catchment was categorized into five erosion categories, namely; low, moderate, high, very high and extremely high, which extend within Kandy, Nuwara-Eliya and Matale districts. All categories were spread both in the left and right banks.

Extremely high erosion areas extend over $24.34 \mathrm{~km}^{2}$ with a percentage of 1.82 , Very high erosion areas extend over $121.24 \mathrm{~km}^{2}$ with a percentage of 906 . High erosion areas extend over $302.91 \mathrm{~km}^{2}$ Proceedings of the International Forestry and Environment Symposium 2006 of the

Department of Forestry and Environmental Science, University of Sri Jayewardenepura, Sri Lanka 
with a percentage of 22.63 , Moderate erosion areas extend over $434.01 \mathrm{~km}^{2}$ with a percentage of 32.43 and low erosion area extends over $454.97 \mathrm{~km}^{2}$ with a percentage of 33.99 . The results of map analysis were confirmed through field verifications. The soil erosion is high in the high slope regions and in the areas where soil conservation methods are inadequate or poor.

\title{
$\underline{035}$ \\ Comparison of litter decomposition rate constant for Yagirala and Horton Plains natural forests of lowland wet zone and montane zone of Sri Lanka
}

\author{
L A M C Amarasekara and D M S H K Ranasinghe \\ Department of Forestry and Environmental Science, University of Sri Jayewardenepura, Sri Lanka.
}

An estimation of rates of litter decomposition was carried out in two forest types; Yagirala Forest Reserve (FR) in the Low Country Wet Zone and Horton Plains natural forest (NF) in montane zone of Sri Lanka. Yagirala forest reserve was located between $6^{\circ} 21^{\prime}$ to $6^{\circ} 26^{\prime}$ north altitude and $80^{\circ} 6^{\prime}$ to $80^{\circ} 1 l^{\prime}$ 'east longitude in the lowland wet climatic zone in Sri Lanka. Horton Plains natural forest was located between $6^{\circ} 47^{\prime}-6^{\circ} 50^{\prime}$ north latitude and $80^{\circ} 46^{\prime}-80^{\prime} 51^{\prime}$ east longitude in mid country of Sri Lanka.

Three $300 \mathrm{~m}$ line transects with three plots ( $100 \mathrm{~m}$ distance between 2 plots) were established in each forest. Litter decomposition rates were determined using the mixed species litter bags method. A total of 54 bags were placed in the both Forests ( 9 replicates for one plot). The experiment was conducted for a period of 8 months. The rates of decomposition of litter recorded during this were fitted to the exponential decay model proposed by Olson (1963).

$x / x^{0}=e^{-k t}$

Where, $x$ is the weight of litter remaining after time ' $t$ ', $x^{0}$ is initial weight of litter and $k$ is decomposition rate constant. Results revealed that the mean annual litter decomposition rate constant for moderately exploited Yagirala forest reserve was 2.19 year $^{-1}$ while the value for Horton Plains natural forest was 1.35 year ${ }^{-1}$. Litter accumulation rates for Yagirala Forest is 668.86 tons $^{-1} \mathrm{ha}^{-1} \mathrm{year}^{-1}$, and this value for Horton Plains natural forest is equal to $226.54 \mathrm{ha}^{-1}$ year ${ }^{-1}$. According to the results, it was clear that Yagirala forest reserve situated in the low country wet zone recorded higher litter decomposition rates compared with Horton Plains natural forest situated in the Montane zone of the country.

\section{6 \\ Development of a rapid environmental assessment methodology for roads sector rehabilitation projects}

\author{
A K Hettiarachchi', N J G J Bandara' and J M S J Bandara ${ }^{2}$ \\ 'Department of Forestry and Environmental Science, University of Sri Jayewardenepura, Sri Lanka \\ ${ }^{2}$ University of Motatuwa, Sri Lanka
}

The concern for the environment is ever growing and counter measures are also taken by many countries to minimize environmental impacts arising from developmental activities. One tool utilised to ensure that developments are sustainable is Environmental Impact Assessment (EIA) which has been a mandatory requirement in Sri Lanka since 1993. However, due to considerable time taken by the EIA process particularly for extensive projects such as road sector projects concerns have been raised as to the delays caused by the process which in certain instances might even cause loss of foreign funds. Although detailed assessments are required in some cases it is not always true. Road rehabilitation projects do not fall into the category of prescribed projects of the National Environmental Act unless sensitive areas are involved and resettlement of more than 100 families are involved. However, foreign funding agencies generally require an environmental assessment of even such projects prior to approving of funding which generally cause delays since environmental assessors tend to follow tire same pattern of assessment for all projects regardless of the scope. Numerous methods have evolved over the years to conduct EIAs some ct which address environmental impact

Proceedings of the International Forestry and Environment Symposium sint of the

Department of Forestry and Environmental Science, University of Sri Ja. .. p pura. Sri Lanka 